\title{
IMPROVED EXPOSURE TO BLUE LIGHT FOR BACTERIAL DEATH OF STAPH.
}

\author{
Endah Robbiyati \\ Program Studi S1 Fisika, Fakultas Sains dan Teknologi, Universitas Airlangga \\ Email: endah.robbivati@gmail.com
}

\begin{abstract}
In this study, bacteria Gram-positive Staphylococcus aureus is exposed to a blue LED light source (light-emitting diode) to determine the appropriate energy to kill the exposure-caused bacteria. The longest exposure times are 1200, 1800, 2400, 3000 seconds, and power 28.098, 56.561, 74.882, and 96.369 MW. The number of bacterial colonies incubated by TPC (total plate number) at 37 degrees $24-48$ hours while the plant is alive. Determine the correct energy caused by exposure to the blue LED lamp, therefore, perform mold analysis, non-compliance, and quantitative energy analysis. These results show that the death of streptococcus skin is generally affected by high energy. From this study, we found that 74,882 MW of energy and $179,716.8 \mathrm{MJ}$ of bacteria per 2,400 seconds were the best energy week.
\end{abstract}

Keywords: Staphylococcus epidermidis, a blue LED, exposure time, the power of exposure, $\mathrm{CFU}$

Latar Belakang Masalah

Epidermis stafilokokus adalah

kartun bakteri dalam tubuh manusia.

Bakteri ini dapat menyebabkan infeksi

jika habitat dipengaruhi oleh

kemampuan jaringan untuk

bereproduksi dan tumbuh dalam

ukuran (Bahaki Ital, 2005) untuk

mengurangi jumlah bakteri yang menggunakan antibiotik (Mitsuka, 1990). Masalah muncul karena bakteri mudah larut sehingga mutasi kebal terhadap antibiotik. Pilih untuk mengurangi bakteri yang diperlukan untuk mengobatinya. Atau, mekanisme fotodinamik telah dikembangkan yaitu teknik radiasi untuk menghambat 
Jurnal Biosains Pascasarjana Vol. 21 (2019) pp

(C) (2019) Sekolah Pascasarjana Universitas Airlangga, Indonesia

bakteri menggunakan molekul mudah digunakan, dan portabel penyerap porfirin.

(Luxion, 2005).

Secara umum, beberapa bakteri

Ada banyak penelitian menghasilkan porphyrin epidermal fotodinamik yang terjadi tentang obatstafilokokus, memproduksi obatan dan undangan. Goldberg dan europorphrin, caproporphren, dan 5-7 para guru (2006) melakukan kontak karboksiporfin. Apa sumber terbesar dengan LED biru, biru, dan merah coproperfen $(74,6 \%)$ (Nietzsche et al., untuk mengobati jerawat, sementara 2004) Porphyrin teradsorpsi dalam LSUD menggunakan fotodinamik. cahaya tampak pada 400-700 nm Penghambatan bakteri patogen LSD (Josinas, 2002). Ini memiliki kapasitas (2005) dan SD Nietzsche dalam penyerapan cahaya tertinggi pada Photodynamics (2004). Aminopanjang gelombang cahaya biru levolinic (ALA) pada bakteri gram (Nietzsche et al., 2004), dan proses positif dan gram negatif. interaksi dengan porfirin disebut Oleh karena itu, berdasarkan fotosensitifitas. (Gross-Weiner, 2005) penelitian sebelumnya dan beberapa Fotosintesis terjadi dalam berbagai fenomena sebelumnya, tujuan dari proses, termasuk fotokopi, fotokopi, penelitian ini adalah untuk fotokopi, dan fotografi.

menemukan jumlah energi maksimum

Dalam komunikasi, sumber yang diperlukan untuk menekan cahaya harus berupa LED (LED), bakteri. Epidermis stafilokokus dengan semikonduktor yang terbuat dari bahan sumber cahaya LED biru lokal, agar ekonomis, ekonomis, 
PROSEDUR PERCOBAAN UJI

POTENSI

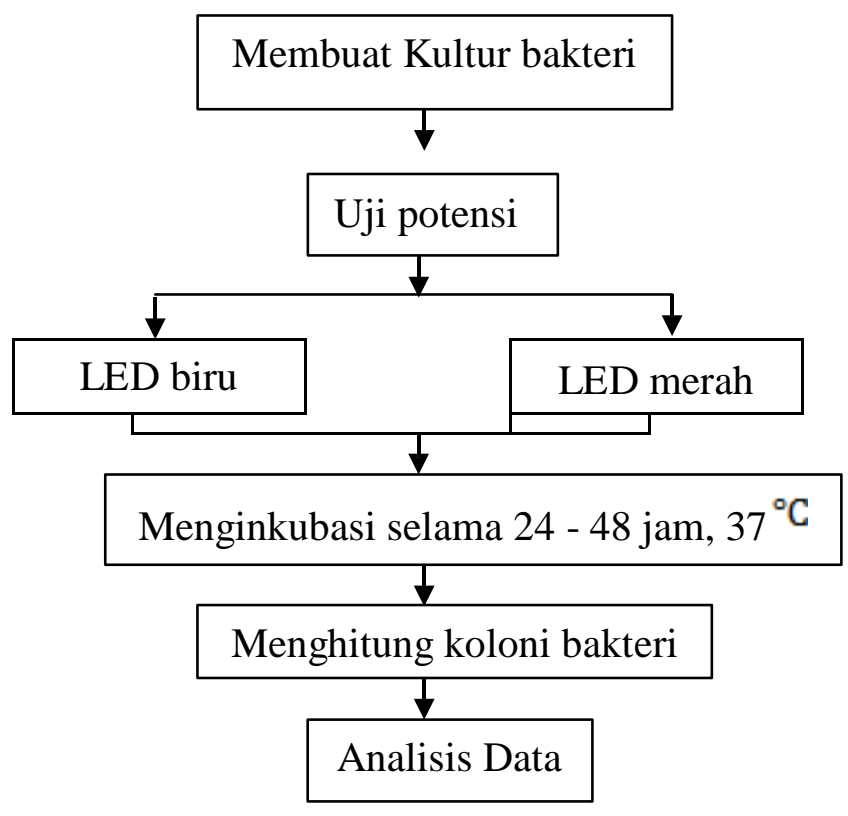

Adapun porsedur penelitian untuk uji

potensi (gambar 3.1) adalah:

\section{A. Mempersiapkan Kultur}

Membuat Stok Infeksi

Staphylococcus epidermis menular

menggunakan setetes dalam wadah

selama 24-48 jam. Sumsum tulang

belakang harus dilokalisasi dan

ditutup dalam sistem peredaran

darah aseptik seperti yang

dijelaskan dalam Lampiran II, dan

ada total 24 jam dalam periode inkubasi. ${ }^{\circ} \mathrm{C}$ pada $120 \mathrm{RPM}$ dalam

blender

\section{Pengenceran}

Setelah dilakukan

inkubasi selama 24 jam, maka

dilakukan pengenceran untuk

memudahkan perhitungan.

Kultur tersebut diencerkan

dengan menggunakan garam

fisiologis steril dengan volume

$18 \mathrm{ml}$ sampai dengan

pengenceran $10^{-5}$. Mengambil

kultur $2 \mathrm{ml}$ ke dalam garfis $\left(10^{-}\right.$

${ }^{1}$ ), lalu dihomogenkan dengan

menggunakan vortek. Hasil

pengenceran pertama diambil 2

ml kemudian dimasukkan ke

dalam garfis $\left(10^{-2}\right)$ lalu

dihomogenkan. Begitu

seterusnya sampai $10^{-5}$.

\section{B. Penyinaran / Treatment}

C. Bilas gelas kultur dengan $0,1 \mathrm{ml}$.

Ikuti LED biru dan merah. 74.882 


\begin{tabular}{|r|r|r|l|r|}
\hline kontrol & $\begin{array}{l}\text { LED } \\
\text { merah }\end{array}$ & $\begin{array}{l}\text { LED } \\
\text { biru }\end{array}$ & $\begin{array}{l}\text { prosentase } \\
\text { LED merah }\end{array}$ & $\begin{array}{l}\text { prosentase LED } \\
\text { biru }\end{array}$ \\
\hline 119 & 67 & 29 & 43.69747899 & 75.6302521 \\
\hline 86 & 66 & 28 & 23.25581395 & 67.44186047 \\
\hline 73 & 65 & 27 & 10.95890411 & 63.01369863 \\
\hline 60 & 41 & 20 & 31.66666667 & 66.66666667 \\
\hline 60 & 40 & 18 & 33.33333333 & 70 \\
\hline \multicolumn{5}{|c}{ MW listrik dalam 2400 jam. Setelah }
\end{tabular}

sintesis, agar Staphylococcus

diadsorpsi dan turunannya Referensi

III. Tahan selama beberapa menit sampai media mengeras, gosokkan ke dalam panci. Kemudian diinkubasi selama 24 jam - $45^{\circ} \mathrm{C}$ hingga $37^{\circ}$

\section{Penghitungan Koloni}

Penghitungan koloni dengan menggunakan hand tolly counter.

\section{Analisis Data}

Penelitian ini menggunakan uji potensi terlebih dahulu sebelum melakukan uji optimasi. Hal ini bertujuan untuk menguji seberapa besar potensi pengaruh pemaparan LED biru dan LED merah, tiap variabel yang berupa faktor daya dan faktor waktu pemaparan terhadap jumlah koloni Staphylococcus epidermidis. Data prosentase kematian bakteri dilakukan penghitungan rumus sebagai berikut:

Prosentase kematian $=\frac{\text { kontrol-perlakuan }}{\text { kontrol }} \times 100 \%$

\section{HASIL UJI POTENSI LED}

\section{MERAH dan BIRU}

\section{Uji Potensi Penyinaran LED biru dan merah}

Data jumlah koloni bakteri yang tumbuh baik untuk kelompok kotrol tanpa penyinaran dan kelompok perlakuan penyinaran LED biru dan merah dilakukan perhitungan jumlah prosentase penurunan koloni bakteri yang tumbuh pada tiap perlakuan dengan menggunakan rumus di atas. 
Jurnal Biosains Pascasarjana Vol. 21 (2019) pp

(C) (2019) Sekolah Pascasarjana Universitas Airlangga, Indonesia

Selain itu, uji-T gratis dengan penurunan jumlah koloni bakteri dua sampel dilakukan untuk memilki variansi homogeny dengan $\mathrm{p}$ menentukan perbedaan radiasi dengan $=0.111(>0.05)$ sedangkan hasil uji $\mathrm{T}$ LED. Persyaratan uji $\mathrm{T}$ untuk dua Independent Sampel Test sampel gratis adalah interval dan data skala rasio dan didistribusikan secara normal.

Hipotesis $\quad: \mathrm{H}_{0}=$ tidak ada perbedaan antara penyinaran LED biru dan merah

$$
\text { : } \mathrm{H}_{1}=\text { ada perbedaan }
$$

antara penyinaran LED biru dan merah

Pengambilan keputussan $\mathrm{H}_{0}$ ditolak jika $\mathrm{p}>\alpha$ (0.05). Hasil uji $\mathrm{T}$ independent test seperti table berikut:

Table Hasil Uji T Independent Sampel Test

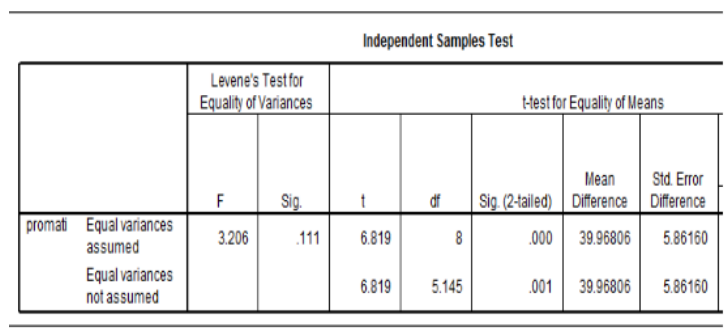

Pada output menunjukkan bahwa uji homogenitas varian data prosentase

\section{DAFTAR PUSTAKA}


Jurnal Biosains Pascasarjana Vol. 21 (2019) pp

(C) (2019) Sekolah Pascasarjana Universitas Airlangga, Indonesia

Badan Pengawas Obat dan Makanan

Republik Indonesia. 2006.

InfoPOM Sibutramin. Deputi

Bidang Obat Tradisional.

Jakarta. Vol 7 No 4

Badan Pengawas Obat dan Makanan

Republik Indonesia. 2010.

Acuan Sediaan Herbal Volume

5. Jakarta

Cabýoglu, M. T., Ergene, N., Tan, U. 2005. The Treatment of Obesity By Acupuncture. Intern. J. Neuroscience, 116:165-175.

Cameron, M. 2013. Physical Agents in Rehabilitation - E Book: From Research to Practice, Fourth Edition. Elsevier Inc.

Desky, B.R.2011.Faktor-Faktor Yang Berhubungan Dengan Obesitas Lansia Di Posyandu Lansia Wilayah Kerja Puskesmas Pb Selayang Ii Kecamatan Medan Selayang Tahun 2011.Medan.Universitas Sumatera Utara

Diamond, J. 2001. The Clinical Practice of Complementary, Alternative, and Western Medicine. United States of America: CRC Press LLC.

Eschleman, M. 1991. Introductory Nutrition and Diet Therapy. U.B Lippincott Company. Pennsylvania. pp. 23

Estunigsih. 2014. Penurunan Indeks Massa Tubuh Dan Lingkar Pinggang Klien Obesitas Dengan Terapi Akupunktur Jin's 3 - Needle Di Desa Tohudan Kulon - Colomadu. Vol 3. No 1. Hal : 33
Focks, C. 2006. Atlas of Acupuncture. Elsevier GmbH. German

Gomez, C.I.G., Guzman, N.E.R., Infante, J.A.G., Jiménez, M.R.M., Cabral, B.D.V., Laredo, R.F.G.2015. Plants With Potential Use On Obesity And Its Complication.EXCLI Journal 14: 809-831

Hermawan, A. G. Komplikasi Obesitas dan Usaha

Penanggulangannya.

Surakarta.Laboraturium Ilmu Penyakit Dalam Fakultas Kedokteran Universitas Sebelas Maret

Ibarra, A., Cases, J., Roller, M., Ripoll, C., Boix, A.C., Coussaert, A.2011. Carnosic acid-rich Rosemary (Rosemarinus officinalis) leaf extract limits weight gain and improves cholesterol levels and gliycaemia in mice on a highfat diet. British Journal of Nutrition

Indriati E. 2010. Antropometri untuk kedokteran, keperawatan, gizi dan olahraga. Yogyakarta: PT. Citra Aji Parama.

Irawan, Agus dan Siti Nurul. 2015 Pengaruh Terapi Totok Perut Terhadap Imt, Lingkar Perut Dan Profil Lipid. Semarang. Universitas Muhammadiyah Semarang

Jie, Sim Kie.1997. Dasar Teori Ilmu Akupunktur. PT Gramedia Widiasarana Indonesia. Jakarta. pp. 14-38

Jie, Sim Kie.2010.Ilmu Titik Akupuntur.TCM 
Jurnal Biosains Pascasarjana Vol. 21 (2019) pp

(C) (2019) Sekolah Pascasarjana Universitas Airlangga, Indonesia

Publication.Singapore. pp. 1450

Kementerian Kesehatan RI. 2015. Pedoman Pembinaan Pengobat Tradisional Akupresur. Direktur Jenderal Bina Gizi dan Kesehatan Ibu dan Anak. Jakarta

NHLBI Obesity Education Initiative. 2000. The Practical Guide Identification, Evaluation, and Treatment of Overweight and Obesity in Adults. North American : National Institutes of Health.

Oviyanti. 2010. Hubungan Antara Lingkar Pinggang dan Rasio Lingkar Pinggang Panggul dengan Tekanan Darah pada Subjek Usia Dewasa. Skripsi. Fakultas Kedokteran Universitas Sebelas Maret. pp. 7-9

Permadi, G. Pong., dan Djuharto S.S. 1982. Pedoman Praktis Belajar
Akupunktur dan Akupunktur Kecantikan. Bandung : Penerbit Alumni

Rustika dan Ratih O.2014. Penyakit Jantung Koroner (PJK) Dengan Obesitas Di Kelurahan Kebon Kelapa.Bogor. Buletin Penelitian Sistem Kesehatan.Vol. 17 No. 4: 385393

Royal College of Physicians of London. Anti-obesity drugs: guidance on appropriate prescribing and management. Royal College of Physicians of London, 2003:1-28

Sahara, M. E. 2006. Rancang Bangun Elektrostimulator Digital Pulsa Spike dan Aquare Beserta Pengendalian Dosis. Skripsi. Fakultas Matematika dan Ilmu Pengetahuan Alam Universitas Airlangga. Surabaya. 